\title{
LAWYERS AND JUdGeS ON CIRCUIT IN CANADA'S NORTHWEST TERRITORIES IN THE TWENTIETH CENTURY
}

\author{
GRAHAM PRICE
}

This article presents a few selected vignettes of lawyers and judges on criminal court circuit in Canada's North during the last century. It seeks to provide a discrete historical database that may be useful to counsel and judges when discharging their northern court duties. It also captures some of the Aboriginal issues that continue to arise in the Northwest Territories and Nunavut.
Cet article dresse le portrait d'un nombre choisi d'avocats et de juges ayant participé à des affaires pénales dans le Nord canadien au cours du siècle dernier. Il vise à fournir une banque de données historique discrète susceptible d'être utile aux juges et aux avocats qui exercent leurs fonctions dans le Nord. Le lecteur y trouvera aussi un aperçu d'un certain nombre d'enjeux auxquels les Autochtones des Territoires du Nord-Ouest et du Nunavut continuent de se heurter.

\section{TABLE OF CONTENTS}

I. Prologue $\ldots \ldots \ldots \ldots \ldots \ldots \ldots \ldots \ldots \ldots \ldots \ldots \ldots \ldots \ldots \ldots$

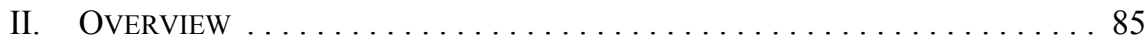

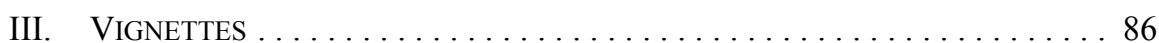

\section{A. DUBUC's CRIMINAL CIRCUITS IN THE 1920S}

IN THE MACKENZIE DisTRICT $\ldots \ldots \ldots \ldots \ldots \ldots \ldots \ldots$

B. Ducharme Trial in 1938 AT Fort SMITH . . . . . . . . . . 88

C. KIKKIK TRIALS IN 1958 AT RANKIN INLET . . . . . . . . . . . . . . . . . 90

D. AiYAOOT/SHOOYOOK TRIAL IN 1966 AT SPENCE BAy . . . . . . . . 93

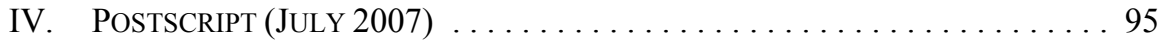

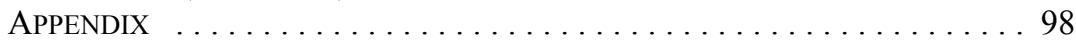

\section{Prologue}

In 1960, the federal government amended the Northwest Territories Act ${ }^{1}$ and established the Court of Appeal of the Northwest Territories. The new appeal court's judges were those already serving on the Alberta Court of Appeal. Effective 1 April 1999, federal legislation established the Court of Appeal of Nunavut. ${ }^{2}$ The Alberta appeal court judges once more stepped forward to serve on this new appeal court.

In the main, the Alberta judges took their added northern responsibilities in stride. Some liked the different focus and found it interesting. Foisy and Hetherington, after leaving the Alberta Court of Appeal, took on appointments as deputy trial judges. Some took pride in their connection to these two northern jurisdictions. Hunt liked to reconnect with the North

Practiced law in the early 1970s in the Northwest Territories (including what is now Nunavut) and subsequently in Calgary; Deputy Territorial Court Judge for the Northwest Territories from 1986-1992; currently a Chartered Arbitrator and Mediator and member of ADR Chambers Alberta. This article in its original form, and now modified, was presented at a symposium, held on 12 October 2007 in Toronto, to mark the 175th anniversary of the opening of Osgoode Hall. For more on the anniversary, see Constance Backhouse \& W Wesley Pue, eds, The Promise and Perils of Law: Lawyers in Canadian History (Toronto: Irwin Law Inc, 2009).

1 An Act to amend the Northwest Territories Act, SC 1960, c 20, s 6.

Nunavut Act, SC 1993 c 28, s 31. 
where she had spent happy times as a young lawyer working for the Inuit Tapirisat. Some were pleased to add "an adventurous touch to their duties." 3 Irving flew his own plane to Yellowknife. Lieberman stayed on after the June sitting in Yellowknife to go fishing at a nearby fishing lodge. Clinton Ford, H.J. Macdonald, and Bruce Smith donned hard hats for an underground mine tour in October 1960 at one of Yellowknife's gold mines. ${ }^{4}$

Some, at times, viewed this responsibility as burdensome. Lengthy travel, especially to Iqaluit on Baffin Island imposed logistical challenges and could be tiring. Initially, the Northwest Territories Court of Appeal only sat once a year in Yellowknife. It now has four regular sittings there per year. The Court of Appeal of Nunavut has three regular sittings per year at Iqaluit. The increasing number of complex cases on the northern appeal court dockets required extensive time commitments. ${ }^{5}$

Some were intrigued when they were exposed to "a rich legacy of Native rights' decisions.... Cases concerning customary marriage and customary adoption, Aboriginal hunting and fishing rights, Native land claims, and discriminatory claims dot the case reports beginning in the late 1950s."6

Some strove to be sensitive to the peculiarities of their new northern jurisdiction. In one of the first cases to come before the Northwest Territories Court of Appeal, the Court noted it should give deference to the trial judge who had a special appreciation for the Aboriginal residents of the North. Justice MacDonald stated: "the learned trial judge has a distinct advantage over the members of this court, for with his wide experience ... he has knowledge of local conditions, ways of life, habits, customs and characteristics of the race of people of which the accused is a member." Some welcomed their involvement in contemporary Aboriginal issues, French language services, and education rights issues, including the question of whether denominational school rights are constitutionally entrenched in the Northwest Territories. ${ }^{8}$

David Mittelstadt, People Principles Progress: The Alberta Court of Appeal's First Century 1914 to 2014 (Calgary: The Legal Archives Society of Alberta, 2014) at 209.

4 A picture of this cand bee seen ibid at 170 . However the clerk, Raoule Esmonde, is incorrectly labelled as Johnson.

See e.g. Fullowka v Royal Oak Ventures Inc, 2004 NWTSC 66, [2005] 5 WWR 420, rev'd (sub nom Fullowka v Pinkerton's of Canada Ltd) 2008 NWTCA 4, 433 AR 69, rev'd 2010 SCC 5, [2010] 1 SCR 132; Canadian (Egg Marketing Agency) v Richardson (1996), 132 DLR (4th) 274, aff'g (1995), 129 DLR (4th) 195 (NWTSC), rev'd [1998] 3 SCR 157.

6 Graham Price, "The North" (1995) 23 Man LJ 352 at 378 [footnotes omitted].

7 Jack Sissons, Judge of the Far North: The Memoirs of Jack Sissons (Toronto: McClelland and Stewart, 1968) at 131-32, quoting Justice MacDonald's reasons in Rv Ayalik (1960), 33 WWR 377 at 378 (NWT CA).

8 As to Aboriginal issues the latest case in point is the ongoing Inuit land claims litigation in Nunavut: NTI $v$ Canada (AG), 2012 NUCJ 11, [2012] 3 CNLR 210, rev'd 2014 NUCA 2, [2014] Nu J No 13 (QL), and the case comment by Nigel Bankes: "Court of Appeal confirms the Availability of a Disgorgement Remedy as a Possible Means of Assessing Damages for Breach of a Modern Land Claim Agreement" (5 June 2014), online: Ablawg.ca <http://www.ablawg.ca/2014/06/05/court-of-appeal-confirms-theavailability-of-a-disgorgement-remedy-as-a-possible-means-of-assessing-damages-for-breach-of-amodern-land-claim-agreement/>. French language services and rights in the Northwest Territories arose in Fédération Franco-Ténoise v Canada (AG), 2006 NWTSC 20, [2006] NWTJ No 33, appeal allowed in part and the cross-appeal dismissed in Northwest Territories $(A G) v$ Fédération Franco-ténoise, 2008 NTWCA 8, 440 AR 56, leave to appeal to SCC refused, 32824 (5 March 2009). The question whether a non-Roman Catholic is eligible for election to a separate school board in the Northwest Territories arose in Yellowknife Public Denominational District Education Authority v Northwest Territories, 2007 NWTSC 15, 283 DLR (4th) 400, aff'd (sub nom Yellowknife Public Denominational District Education Authority v Euchner), 2008 NWTCA 13, 446 AR 221. 
This article presents a few selected vignettes of lawyers and judges on criminal court circuit in Canada's North during the last century. It is a modest attempt to replicate the colourful stories of Irish lawyers in the The Old Munster Circuit. ${ }^{9}$ It seeks to provide a discrete historical database that may be useful to counsel and judges when discharging their northern court duties. It also captures some of the Aboriginal issues that continue to arise in the Northwest Territories and Nunavut.

\section{OVERVIEW}

Towards the end of the twentieth century, major boundary changes radically reconfigured the Northwest Territories. In 1905, Alberta and Saskatchewan, newly created, were cut from its southwestern underbelly. Seven years earlier, the Yukon had been carved out. Then in 1912, Ontario, Quebec, and Manitoba expanded north to their present sizes. Boundary adjustments then abated for a time. Eighty-seven years passed. In 1999, the newly constituted territory of Nunavut appropriated the eastern and central Arctic. This left the Northwest Territories as essentially the Mackenzie River drainage basin and the western Arctic islands.

In the early part of the last century, except in the Yukon, accused were brought south to the provinces for trial. By the early 1920s court parties went north to take justice to the people. Climate and geography played their part in this decision. In the Mackenzie River drainage basin, until air travel became prevalent in the 1930s, summer circuits were the rule. Only during warm weather could court parties travel by open water to isolated communities. In the central and eastern Arctic, summer water circuits were sporadic. ${ }^{10}$ In the central and eastern Arctic, now Nunavut, air circuits only came after the Second World War.

The lawyers and judges who went on circuit, non-residents, and later resident northerners, played their role in the circuit ceremony and procedure. They observed the effect, or apathy, the court's presence had on local Inuit and Dene. They worked with interpreters, adapted to a flexible court schedule, packed a rudimentary circuit library kit, and lodged among the settlement inhabitants. One English circuit commentator has said of another time and place that the court party could be likened to an "Asiatic caravan, taking all their books, records and impedimenta with them." 11

By the late 1950s, encouraged by first Justice Jack Sissons and then Justice Bill Morrow, lawyers as part of this remarkable traveling circus grew more sophisticated. The truncated justice of an earlier era gave way to more intricate, nuanced dispositions. Joseph, 1939).

10 In this article I do not discuss the Janes murder trial held at Pond Inlet in late August 1923. The court party, all from Quebec, traveled on the CGS Arctic to the northern tip of Baffin Island. The court party left Quebec City on 7 July, returning on 4 October. Shelagh D Grant, Arctic Justice: On Trial for Murder, Pond Inlet, 1923 (Montreal: McGill-Queen's University Press, 2002) at 156-86.

11 The Honourable Sir William Mars-Jones, "Beeching - Before and After on the Wales and Chester Circuit" (1973) 4 Cambrian LR 81 at 82. 


\section{VIGNETTES}

\section{A. DubuC's CRiminal CirCuits in the 1920S IN THE MACKENZIE DISTRICT}

In August 1917, Sinnisiak and Uluksuk, two Copper Inuit, were tried in Calgary for the murder, near the mouth of the Coppermine River on the arctic coast, of the Catholic priest father Le Roux. ${ }^{12}$ Earlier that month, in Edmonton, Sinnisiak as the only defendant had been acquitted by a jury of the murder of father Rouvier, Le Roux's partner. These two Inuit were the last to be brought south to the provinces for trial.

By 1920, realizing trials in the provinces presented grave difficulties, the federal Department of Justice instituted a policy change. ${ }^{13}$ Thereafter trials would be held "on the spot." Hence, in the summer of 1921, Lucien Dubuc, a judge resident in Edmonton, proceeded north by rail and water to Fort Providence on Great Slave Lake accompanied by "southern" counsel. There he presided over the murder trial of Le Beaux. In the summer of 1923, his court party travelled further down the Mackenzie River going to Herschel Island, off the Yukon coast in the Beaufort Sea. There he presided over the Alikomiak murder trial. Dubuc then led subsequent summer circuits down the Mackenzie River in 1924, 1926, 1929, and $1931 .{ }^{15}$

Not surprisingly, counsel's fees became an issue. The branch of the then federal Department of the Interior charged with the administration of justice in the Northwest Territories had not budgeted for counsel fees. It believed the appointment of private lawyers would lead to high trial costs. If in-house counsel were utilized, counsel fees would be kept within manageable limits. But with what consequences?

In 1921, at the Le Beaux murder trial at Fort Providence, C.C. McCaul of Edmonton prosecuted and in-house counsel J.G. Cory of Winnipeg acted for the defence. ${ }^{16} \mathrm{McC}$ aul was an exceedingly experienced counsel who had practiced in such diverse jurisdictions as Dawson in the Yukon, during the gold frenzy, and later in San Francisco before ending up in Edmonton. ${ }^{17}$ Fresh from his experiences prosecuting Uluksuk and Sinnisiak in Edmonton and Calgary in 1917, McCaul had a distinct advantage over his opposite number who owed his counsel appointment to his father W.W. Cory, the Commissioner of the Northwest Territories. ${ }^{18}$ Convicted, LeBeaux was hanged later that year. ${ }^{19}$

See Edwin R Keedy, “A Remarkable Murder Trial: Rex v Sinnisiak” (1951) U Pa L Rev 48 at 64-65. The reasons for the change are set out in Graham Price, Remote Justice: The Stipendiary Magistrate's Court of the Northwest Territories (1905-1955) (LLM Thesis, University of Manitoba, 1986) at 216-18 [unpublished] [Price, Remote Justice].

Ibid at 22-23, 217-18, 220 .

Ibid at $68-73,223$.

Ibid at 377; Cornelia Schuh, "Justice on the Northern Frontier: Early Murder Trials of Native Accused" (1979) 22:1 Crim LQ 74 at 85.

Alan D Ridge, “C.C. McCaul, Pioneer Laywer" (1973) 21:1 Alberta Historical Review 21.

"Memorable Manitobans: William Wallace Cory (1965-1943)," online: The Manitoba Historical Society $<$ http://www.mhs.mb.ca/docs/people/cory_ww.shtml $>$.

Grant, supra note 10 at 49. 
In mid-July 1923, T.L. Cory, who was J.G.'s brother, defended Alikomiak, an Inuit charged with the murder of RCMP officer Doak. ${ }^{20}$ I.B. Howatt, K.C. a practising lawyer in Edmonton, prosecuted. Cory, an in-house solicitor at the federal Department of the Interior, exhibited negligible criminal counsel skills. This was unfortunate for the accused, though on the evidence a conviction was almost certain. What was more unfortunate was Cory's apparent predetermination of the case. Writing in September of 1922 to his superiors, almost a year before the trial, he observed clemency and kindness toward the Inuit had not worked, and those Inuit found guilty of murder "should receive the utmost penalty" and be hanged. ${ }^{21}$ And Alikomiak was — hanged that is!

The next year, both counsel on Dubuc's circuit were lawyers in private practice from Edmonton; I.B. Howatt again prosecuted and Boyd McBride acted as defence counsel. ${ }^{22}$ Unlike the Cory brothers, McBride was feisty and aggressive - he left a forceful impression. His client was well represented, though he was still convicted. This trend of using private practising lawyers instead of in-house ones continued for Dubuc's last two circuits in 1926 and 1929, and the territorial administration continued to complain about counsel fees.

Counsel who accompanied Dubuc down river on circuit endured some hardship. In 1923, they embarked on a journey lasting over three months. Leaving Edmonton on 12 June they travelled by rail to Fort McMurray and then via the Athabasca River to Fort Smith just inside the Northwest Territories. ${ }^{23}$ Aboard the Hudson Bay Company's S.S. Distributor, they steamed across Great Slave Lake and down the Mackenzie River to Aklavik in the Mackenzie Delta. The final leg of the journey west along the Beaufort Sea coastline was accomplished in two stages: first by motor scow to Shingle Point and then the remaining 50 miles on the Hudson Bay schooner Aklavik through the drift ice. Arriving on 16 July they then either went about their court business or waited around until leaving on 12 August to retrace their steps. Back in Edmonton on 21 September counsel could relive the sense of adventure spiced with trepidation they had experienced. They had just returned from the Mackenzie District of the 1920s, described graphically by one commentator:

\footnotetext{
Living among, or dependent upon the native population of the Mackenzie basin ... was a fluctuating number of whites - trappers and prospectors, traders, mission workers, agents of the government, a few artisans and transportation employees. These included the inhabitants of the forty or fifty tiny settlements, many of them a century old, which hugged the waterways ... [down] to Aklavik. Despite their age they remained pioneer communities, outposts of white settlement in the midst of hundreds of miles of wild, virtually empty territories, and inhabited mostly by relays of transient white residents. ${ }^{24}$
}

In Dubuc's 1924 circuit, counsel were required to put in long hours in unusual surroundings. Beginning in the morning on 7 July, Dubuc conducted proceedings on the

Graham Price, "The King v Alikomiak (aka Alicomiak, aka Alekamiaq)"(1991) 20:1 Man LJ 204. Letter from TL Cory to OS Finnie, Director of the Northwest Territories Branch of the Department of the Interior (12 September 1922) in KS Coates \& WR Morrison, “"To Make These Tribes Understand': The Trial of Alikomiak and Tatamigana" (1998) 51:3 Arctic 220 at 225.

Price, Remote Justice, supra note 13 at $223,379$.

Ibid at 227, 377-78.

Morris Zaslow, The Development of the Mackenzie Basin, 1920-1940 (PhD Thesis, University of Toronto, 1957) at 608. 
foredeck of the docked S.S. Distributor. ${ }^{25}$ Taking advantage of the constant daylight, the trial extended from early morning right through to the jury verdict received at 2:00 a.m. the next day. On his 1929 circuit, Dubuc for a change of pace moved inside and conducted trials in the ship's saloon. ${ }^{26}$

\section{B. DUCharme Trial in 1938 at Fort SMith}

In late October 1938, Charles Perkins, a lawyer living in Yellowknife, found himself in Fort Smith acting as defence counsel for Ducharme, who was charged with rape. ${ }^{27}$ Perkins recollects: "Ottawa seemed to be particularly concerned, because the white husband of the Indian woman [allegedly raped] had threatened violence. He was an astonishingly accurate shot, so I was told, and considered to be rather a dangerous, eccentric man."28

Perkins' appointment to act was one of a number of unusual features of the case. Originally the federal Minister of Justice appointed Jack Gibben to act as defence counsel. ${ }^{29}$ However, Gibben, a lawyer recently arrived from Winnipeg, had not yet been admitted to practice under the Legal Profession Ordinance. Fearing a protest from Perkins, admitted to practice in May of 1938 and holding Certificate No. 1 under the Ordinance, the Department of Justice appointed Perkins. Stipendiary Magistrate McKay Meikle, who was not legally trained yet heard the case, was instructed to make the "best possible deal [as to fees with Perkins] ... so that any needless expense may be avoided." ${ }^{30}$ That the judge was negotiating Perkins' fee did not seem to trouble anyone! Incidentially, from a cost point of view, the best would have been for the RCMP to prosecute, Gibben to defend and Meikle to preside.

More unusual was the fact Gibben, then appointed to prosecute, also held an appointment as a Stipendiary Magistrate. He had taken the oath of judicial office in August 1938. ${ }^{31}$ R.A. Gibson, Deputy Commissioner of the Territorial Administration, suggested and federal Department of Justice agreed it was preferable (from a cost perspective) to have two legally trained counsel - Gibben and Perkins - assist the non-legally trained Meikle. The alternative was to pay for two independent counsel, have Gibben preside wearing his judicial hat, and let Meikle stand idly by. This cost-saving rationalization was deplorable. Oddly as a sitting judge, Gibben received his permit to practice law under the Legal Profession Ordinance on 24 November $1938 .{ }^{32}$

Perkins takes up the tale:

[The night before the trial, a] young RCMP came in and told me he had been detailed to sit in the lobby of the old Mackenzie House all night. I asked him why. He said (the husband) was loose in the settlement and had threatened to kill anybody connected with the trial. Although Gibben and Meikle pooh-poohed the whole

Price, Remote Justice, supra note 13 at 379-80.

Counsel appeared at the Bar within a bar. Ibid at 380-81.

Ibid at 384.

Charles Perkins, in Yellowknife Tales: Sixty years of stories from Yellowknife (Yellowknife: Outcrop, 2000) 13 at 15 .

Price, Remote Justice, supra note 13 at 384.

Letter from RA Gibson to Plaxton, Deputy Minister of Justice (29 October 1938) cited in ibid at 260.

Price, ibid at 104.

Based on author's research. 
thing, I began to feel a certain amount of uncertainty. Apparently I had some reason for it. When I woke up in the morning, the husband was sitting in a chair two or three feet from my head with a rifle pointed at me.

As soon as we began to talk, I realized that he was very disturbed but not motivated by any particular animosity towards me. He poured out a long story of the awful difficulties he had encountered in taking his Indian wife back to his family. It was a very sad case. I persuaded him to put his rifle down and we walked down stairs past the sleeping policeman and woke him up. We all sat down at the table and had breakfast together. $^{33}$

As the facts emerged at trial, the Crown's case began to look "extremely shaky." ${ }^{34}$ So over lunch counsel discussed the case with Meikle. The judge was concerned an acquittal might provoke some serious reaction by the husband or the Dene in the settlement. So when Ducharme was acquitted on the rape charge, the police immediately laid a charge of common assault. Ducharme pleaded guilty to that charge and was sentenced to a month in jail. Perkins adds, "[t]his was typical of Meikle, who had a great fund of common sense and really no legal knowledge at all." ${ }^{35}$ Unfortunately for Ducharme, Gibben and Perkins did not address the principle of included offences and the plea of autrefois acquit. An acquittal for rape probably precluded a subsequent conviction on the subsequently laid charge of common assault arising out of the same set of circumstances. ${ }^{36}$

Gibben went on to be a judge of the Yukon Territorial Court at Whitehorse, taking up his appointment in 1950. His clerk paints this engaging portrait of him:

Gibben, John E., was a little man, physically, not much over five foot, chubby, rosy, well-scrubbed. Immaculate in dress. The last is a key word. The first impression of Gibben was that he had just emerged from a shower, parboiled \& pink, barbered with extreme care, then clothed in fresh linen.

I always thought him temperamentally unfitted to be a judge. He felt strongly for people and, through empathy, became deeply involved, emotionally, in the cases that came before him.

Sentencing in criminal cases was very much an ordeal for him — in imposing heavy sentences he was likely to choke up and tears were not far away.

Sordid cases, I think, left him with a feeling of having been personally besmirched. At the end of the day's sitting, he would shower interminably — as though to wash away the stains. ${ }^{37}$

Perkins too became a stipendiary magistrate, replacing Gibben in August 1941. He, like Gibben, empathized strongly with people and their problems. ${ }^{38}$

To be fair to Perkins and Gibben, the jurisprudence on this special plea was "skimpy" in the late 1930s. The fifth edition of Tremeear's published in 1944 discusses this plea in much greater depth: Alan Burnside Harvey, ed, Tremeear's Annotated Criminal Code Canada, 5th ed (Calgary: Burroughs, 1944) at 1129. Interestingly, the editor of the fifth edition was the son of Horace Harvey, long-time Chief Justice of Alberta.

37 J Worsell, letter to G Price dated 13 January 1977 at 1-2 (on file with author).

38 Price, Remote Justice, supra note 13 at $91,101$. 


\title{
C. KIKKIK TRIALS IN 1958 AT RANKIN INLET
}

Kikkik, a petite Inuit woman, appeared before Justice Sissons and a jury in Rankin Inlet, on 14 April, 1958, charged with the murder and abandonment of two of her children. The case attracted enormous attention at the time. Time Life sent a reporter to the trials. Maclean's wrote of it. ${ }^{39}$ So too did Sissons ${ }^{40}$ and Frank Wade ${ }^{41}$ and Farley Mowat. ${ }^{42}$ Kikkik presented as a sympathetic figure caught in a terribly unfortunate situation. Sisson's pithy account of the facts is poignant and heart-rending.

\begin{abstract}
Kikkik's family and that of her half-brother Ootuk were caught in January at Henik Lake, about half way along the trail to the coast. Both families were trying to survive on the fish Kikkik's husband Hallow was catching through the ice.
\end{abstract}

On February 8th Ootuk shot Hallow; Kikkik then stabbed Ootuk to death. For this she was charged with murder.

Eight days later, trying to guide her five frightened children across forty miles of drifted tundra to the safety of the Hudson's Bay Company post at Padlei, she left two of them beside the trail in an igloo. One of the children died before rescue came. For this she was charged with abandoning her daughter Annecatha and causing through criminal negligence the death of her daughter Nesha. ${ }^{43}$

At her murder trial, Kikkik successfully pleaded self-defence and was acquitted by the jury after only retiring for ten minutes. At her second trial for abandoning her two children, the jury also acquitted.

John Parker, a lawyer who had practiced in Yellowknife since 1944, prosecuted. Hal Parkes, one of his former court reporters described Parker as astute, calm and dignified and who spoke with an accent all his own. ${ }^{44}$ Originally from Ontario, he had practiced briefly, just before the war, in Kirkland Lake in northern Ontario. After serving in the war, he went to Yellowknife in late 1944. His clerk, when Parker was later a justice of the Territorial Court at Whitehorse in the Yukon, comments on Parker's time at Yellowknife:

I gathered, from Parker, that his years in Yellowknife were happy ones. [He] [s]eems to have had a strong rapport with the mining fraternity there — well in with Giant Yellowknife [mine], may have been their lawyers. [He had] [e]xtensive knowledge of the mining industry and financial aspects thereof.

Residents of Yellowknife, who knew him there, have, unfairly I think, described him to me as the laziest man in Yellowknife. This was based, perhaps, on John's faculty for making things look easy, by being forever

Farley Mowat, "The Two Ordeals of Kikik" Maclean's Magazine (31 January 1959) at 12.

Sissons, supra note 7 , ch 21.

Frank Wade, Advocate for the North: Judge John Parker, His Life and Time in the Northwest Territories 1944-1958 (Victoria: Trafford, 2004) ch 11. Wade wrote of Parker's recollections.

Farley Mowat, The Desperate People (Boston: Little, Brown \& Co, 1959) ch 13.

Sissons, supra note 7 at 99.

Hal Parke's discussions with author in Winnipeg in the spring of 1976. See also Worsell, supra note 37 (discussing Parker's "Harvard accent" at 4). 
cool, nonchalant. He kept, they said, atrocious office hours - strolled to work when the weather was fine — took a taxi when it was inclement. It is characteristic that he never owned a car in Yellowknife. With [extreme practicality], he perceived that there were only a few miles of road on which to drive - and further, that in cold weather [it was] much more comfortable to [phone a] taxi than to struggle with a recalcitrant motor. $^{45}$

Sterling Lyon defended. Lyon was appointed by the federal Department of Justice because he had been "highly recommended" and was "thoroughly qualified to conduct the defence of the accused." ${ }^{\prime 46}$ Lyon had been a Crown attorney in Winnipeg before going into private practice. After the trial he returned to Manitoba, ran for public office, and later became Attorney General and then Premier of Manitoba. ${ }^{47}$ Before the two trials started, Parker welcomed Lyon to the Northwest Territories bar as someone thoroughly versed in the criminal law. ${ }^{48}$

Lyon recounted his tactics at the murder trial:

I didn't think I had to [put my client on the stand]. That's always a risk that the defence counsel takes. But in this case, through the Crown's case I had gotten in most of what I had wanted to get in. Her statement to the police was really not an inculpatory statement in the sense that she admitted murder. She admitted the homicide of a man but it was clearly self-defence. ${ }^{49}$

Lyon had the added advantage that Ootuk was a shaman who struck fear into some of the group. ${ }^{50}$

The trial transcript reveals Parker acted "with the utmost fairness." exhibited a high degree of cooperation and competence. Portions of Kikkik's statement were put in by consent. Parker interjected to ensure Lyon got the answers he was seeking. Parker did not ask for a murder verdict. Sissons complimented them both for their efforts in making the jury's task much easier. Even a bit of levity crept in:

The Court [of Howmik, Ootuk's wife]: Are you a Christian?

Answer: Yes

The Court: What church?

Answer: Both of them.

Worsell, ibid at 3-4.

$R v$ Kikkik (14-16 April 1958), Rankin Inlet E1-472 (NWT Terr Ct) (transcript of the trial proceedings at 2-3) [Kikkik transcript].

Wade, supra note 41 at 189; "Former Manitoba premier Sterling Lyon dies" CBC News (16 December 2010), online: http://www.cbc.ca/news/canada/manitoba/former-manitoba-premier-sterling-lyon-dies1.881868 ["Sterling Lyon dies"].

Kikkik transcript, supra note 46 at 3.

Dorothy Harley Eber, Images of Justice: A Legal History of the Northwest Territories and Nunavut as Traced Through the Yellowknife Courthouse Collection of Inuit Sculpture (Montreal: McGill-Queen's University Press, 2008) at 68-69.

Ibid at 62-63.

Kikkik transcript, supra note 46 at 84. 
Mr. Parker: A very wise precaution, My Lord. ${ }^{52}$

Both counsel went to the bench. Parker took an appointment later that year replacing Gibben as justice of the Territorial Court in the Yukon. Of his time there his clerk adds:

[He] obtained his judge's appointment during [the] short-lived conservative regime.

Did he know any law? This is a rather hazy area. In all the time I knew him, I never recall him cracking a law book — nor did he ever take a crammed briefcase home with him. Yet he functioned without strain — made it all look effortless - and occasionally astonished counsel before him by exhibiting complete familiarity with cases cited. Memory, maybe.

Most [colourful] on the bench. Completely at ease. Tilted [his chair] back, scanned the ceiling, feigned sleep. Then shook everyone by apparently regaining consciousness and being perfectly cognizant of all that had been said. A beautiful performance.

Educated, in some part, in the US. A Harvard accent. An incident in point — A newly-appointed Q.C., appearing before him for the first time after [his appointment], was being rather tedious. Parker said, "Mr. W., you are a silk. Please get on with it." What Mr. W. heard was this, "Mr. W., you are a soak. Please get on with it." He was shaken to the core, particularly since his drinking habits were no secret. In disarray, he got on with it as best he could, but didn't regain his composure until, at recess, he checked the [reporter's notes].

Parker was wont to bat out judgment from the bench, often without so much as a brief recess. This was often deflating to counsel who had laboured [long and] hard to becloud the issue. Often, he would incisively cut away the verbiage and reveal the real issue.

If, as he rarely did, he reserved judgment, it would be long in forthcoming. Sometimes it would never be delivered. Complete inability to go back \& work at it cold.

Parker's philosophy - I may be wrong. If I am, the Court of Appeal will set me right. That's their job. Why then, should I exercise myself unduly with this matter? It was easier to appeal than in Gibben's day. Litigants had more money. Vancouver was, somehow, closer. Counsel welcomed a trip Outside. Strangely enough, his score on appeals was surprisingly good. Upheld as often as not and, in the meantime, he saved himself a lot of agonizing.

$[\mathrm{H}] \mathrm{e}$ was not deeply "learned in the law." But I had, ... the greatest respect for his intellectual powers. Perhaps it goes to prove that with INTELLIGENCE, an encyclopedic knowledge of the law is not essential to being a good judge - a great one, maybe. Stupidity on the bench is not unknown, though, fortunately, it is less rampant than in other walks of life. ${ }^{53}$ 
Lyon's ascent to the bench took longer. Only after his political life ended did he take an appointment, in 1986, to the Manitoba Court of Appeal, from which he retired in 2002. ${ }^{54}$

\section{AIYAOOT/SHOOYOOK TRIAL IN 1966 AT SPENCE BAY}

\section{One of the defence counsel set out the logistics surrounding this particular trial:}

In addition to judge, clerk, court reporters, and three lawyers, there was a full coterie of witnesses and observers: Dr N. MacPherson, of the Alberta Hospital, who would testify for the crown; Dr Young, an Edmonton psychiatrist and the RCMP's rifle expert, for the defence; Farley Mowat, the celebrated writer, representing Maclean's magazine; several members of the press from across the nation; and Brian Purdy, a young lawyer newly arrived in Yellowknife. The party also included a cook who brought along enough food to cover our stay since there were no hotels or other facilities in Spence Bay. ${ }^{55}$ jury:

David Searle of Yellowknife prosecuted. He set out the facts in his pithy opening to the

In July of 1965, approximately twenty persons, including men, women and children, were living on the land as hunters and trappers at Old Fort Ross in Levesque Harbour on Boothia Peninsula, approximately 200 miles north of Spence Bay. There is no RCMP detachment there, no Northern Affairs Officer, no nursing station, and no Hudson's Bay Company post. In the summer these people live in tents, in the winter they live in snow houses. There is no road communication with Spence Bay, nor is there any regular air service.

[Y]ou will hear what happened at Fort Ross in July of 1965. You will hear about Soosee, the deceased woman, mother of the accused Aiyaoot, and wife of Napachee-Kadlak. You will hear about the extreme pain and hardship Soosee, because of her [schizophrenia] illness, caused the rest of her group... These witnesses will describe how the deceased was bound hand and foot as a means of restraint, and how she got loose. You will be told about everyone moving, except Soosee, to an island (a half mile offshore).

For four days everyone except Soosee of course remained on the island, hoping it seems that Soosee would wander off into the land and away from the camp. Through a telescope Soosee was observed throughout the four days. She was observed tearing down the tents, and breaking up the equipment.

On or about the 15 th of July, 1965, the decision was made that something must be done. You will hear about the decision to have a man or two men go from the island to Soosee in the hope of determining whether she was still upset by the devil. If she was still upset by the devil, she was to be encouraged to run away, or in other words, she was to be scared away. If she wouldn't scare away, then she was to be shot.

The Crown's case of course is to prove that the two men who went to Soosee, first to determine her condition, second to scare her away if her condition was still bad, and third, to shoot her as a last resort, were Aiyaoot and Shooyook, the two accused.

"Sterling Lyon dies," supra note 47.

WH Morrow, ed, Northern Justice: The Memories of Mr Justice William G. Morrow (Toronto: Osgoode Society for Canadian Legal History, Legal Archives Society of Alberta, 1995) at 68. Farley Mowat wrote about the case: Farley Mowat, The Snow Walker (Toronto: McClelland and Stewart, 1975) at 183. 
Lady and gentlemen of the jury, this is a difficult case. Our sympathy must be with these people who found themselves in this impossible situation. Your job is to hear the evidence, to take instructions on the law from His Lordship, to consider the facts, and to determine whether the two accused be guilty or not guilty. I do not envy you your task. ${ }^{56}$

Approximately five years at the bar at the time of trial, Searle was an ambitious, focused counsel. A graduate of the law school of the University of Alberta in Edmonton, he took over Crown counsel duties when the federal Liberals came to political power in $1963 .{ }^{57}$ Possessed of a courtroom presence and a sense of the theatre that can be a courtroom, he brought considerable criminal counsel skills to the trial.

Bill Morrow appeared for Shooyook. A lawyer of enormous talent, energy, and drive, he had practiced in Edmonton since just before the Second World War. He first came North on criminal court circuit in 1960. Justice Sissons had presented him with a challenge he could not refuse. In the absence of legal aid, if Morrow would act as defence counsel he could come on the April circuit. The circuit lasted eleven days and Morrow was paid $\$ 10$ a day by the Canadian government. ${ }^{58}$

When called upon to defend, under an appointment by the Minister of Justice, he found himself at the Preliminary Inquiry in February 1966 under adverse weather and accommodation conditions. The temperature was almost $-80^{\circ} \mathrm{F}$ with the wind chill factor. His bed was a mattress on the floor in a construction shed with an oil stove in the middle of the room for heat. ${ }^{59}$ For the trial itself counsel graduated to the schoolroom floor. Morrow's fees were modest. After payment of his expenses, he netted $\$ 75$. He bought his client a new rifle with it. ${ }^{60}$

Howard Irving acted for Aiyaoot. He was brought in after the preliminary. A lawyer of high calibre, he practiced with a large firm in Edmonton. Shrewd and calculating, he waived a preliminary inquiry and elected not to delay the trial. His low-key approach at trial worked: his client was acquitted.

Brian Purdy, newly to Yellowknife, at Sissons' request came along to even up the number of lawyers on each side. ${ }^{61}$ Asked to robe and sit with the prosecutor, this left two lawyers on each side of the counsel table.

Purdy wrote eloquently of the flight to Spence Bay:

I have read of the Arctic having a "terrible beauty," and to look out the window of the plane as you cross it, is to understand that phrase perfectly. Beneath you is a vast plane of white. Some of it is land, and some of

56 Sissons, supra note 7 at 181-82. See also $R v$ Shooyook and Aiyaoot, transcript of trial conducted at Spence Bay on 15 and 16 April, 1966, Yellowknife Court Records at 23-25 [Shooyook and Aiyaoot transcript].

Conversation with David Searle in 1971

Morrow, supra note 55 at 56.

Ibid at 67.

Ibid at 70 .

Conversation with Brian Purdy in October 2007. See also B Purdy, Memoirs of a Courtroom Lawyer [unpublished] at 97-98 [Purdy, Memoirs]. 
it is ice, and often you cannot tell the difference. The sun sits low on the horizon, and you are in a perpetual twilight during the day. The light is golden. Haze obscures the horizon at all times, and there is no definite line between earth and sky. You drone above this endless white, realizing more with each passing hour how huge and empty is this Canadian North. There are no signs of life. It is very hard to think of it as Canada. It is more like flying over Mars or the Moon, not a place with people. You find yourself noting details in the landscape. You see rocks sticking out of the snow, and know you are above land. Later there are open leads of water, or polynias, and you know you are over the ocean. The snow itself is shaped by the wind, and often forms long parallel banks, which can be seen from the plane. ${ }^{62}$

Purdy practiced in Yellowknife until the late 1970s and then joined the federal Department of Justice in Vancouver. He was defence counsel in the Drybones case ${ }^{63}$ arguably the most important case under the Canadian Bill of Rights. ${ }^{64}$

The trial took only a day and a half. Court opened at 8 a.m. on 15 April in one of the schoolrooms in the settlement's only school. After jury selection, Court adjourned to the next morning. By the next evening, counsel were summing up. The jury verdict came in at 11 p.m. that night. Shooyook, found guilty of manslaughter, was given a suspended sentence. ${ }^{65}$

For the trial, bilingual Inuit were in short supply. The two chosen for jury duty spoke little English. During their deliberations, the jury foreman asked for an interpreter. Searle made the sensible suggestion that an Inuk could speak and understand English but still need an interpreter for complicated concepts. Morrow objected and Sissons, sensitive to the possibility of a mistrial, declined the foreman's request. ${ }^{66}$

Both Morrow and Irving ended up on the Alberta Court of Appeal. Morrow took a circuitous route replacing Sissons later in the fall of 1966. He served for 10 years as the second "Judge of the Far North"67 in Yellowknife before moving to Alberta in 1976.

\section{POSTSCRIPT (JULY 2007)}

From the setting of the Chief Judge's private chambers in Yellowknife on a day in late July 2007, Justices Ted Richard and John Vertes reminisced on the criminal circuit system in the Northwest Territories. ${ }^{68}$ Much has changed. Counsel miss the camaraderie of the court party when all travelled together on chartered aircraft. Now, counsel and the Court travel by scheduled aircraft into many of the communities. The lawyers go in advance of the Court to meet with their clients. Charter aircraft is now little used in the Northwest Territories, though it remains a feature of the circuit system in Nunavut.

\footnotetext{
62 Purdy, Memoirs, ibid at 99.

$63 \quad R v$ Drybones (1967), 60 WWR 321 (NWT Terr Ct), aff'd (1967), 64 DLR (2d) 260 (NWT CA), aff'd (1969), [1970] SCR 282.

SC 1960 , c 44.

Sissons, supra note 7 at 185-86.

Shooyook and Aiyaoot transcript, supra note 56 at 150-51.

Jack Sissons being the first. Sissons, supra note 7.

Discussion in Yellowknife at the court house with Justice Ted Richard and Justice John Vertes in late
} July 2007. 
Counsel do not miss the uncertainties surrounding court facilities and accommodations while on circuit. Courthouses now dot the major communities in the Northwest Territories. The Court no longer holds its sessions in churches or rundown recreation halls. In smaller communities without courtroom facilities, modern schoolrooms or recreation halls are used. Accommodations are no longer rudimentary, although they are not sufficient in all communities. This means trials must sometimes be brought into larger communities.

In the main, counsel on circuit maintain a good working relationship. Since the late $1950 \mathrm{~s}$, the Crown has made full disclosure of its file to defence counsel. This presaged by approximately 40 years the Stinchcombe rules $^{69}$ that formalized Crown disclosure to the defence.

The composition of circuit counsel has changed. The private bar does not participate as it previously did. Several major Canadian law firms have branch offices in Yellowknife. They keep their lawyers occupied with the lucrative work resource companies provide. Typically now, two or three legal aid staff lawyers attend at most criminal circuits. These staff lawyers work out of legal aid clinics strategically located in several communities. No longer are there informal Department of Justice appointments or requests made by the court of the private bar that characterized defence counsel appointments up to the early 1970s. After that, a comprehensive legal aid system was introduced and for a period of time the private bar took turns going on circuit.

Finally, counsel no longer appear before a judge who was a legend during his own lifetime. No one has replaced Jack Sissons. This is the man whose mother's cousin was the famous David Livingstone, the African explorer, whose exploits imbued Sissons with a sense of adventure. ${ }^{70}$

That sense of adventure led Sissons to take the court on circuit throughout the Northwest Territories. Sometimes his circuits consisted of arduous treks in the middle of winter over Foxe Basin in a single-engine Beaver aircraft. The temperature was $-45^{\circ} \mathrm{C}$ during the three hours of daylight and colder at night. ${ }^{71}$

This was the Sissons captivated by the Inuit culture, their perseverance in a harsh environment, their ingenuity, and problem-solving abilities. From this respect emerged his fierce determination to uphold the customary legal rights of the Inuit.

The last word will go to his faithful, sometime clerk:

There was a man.

Human, down-to-earth, without affectation or artifice. Crippled (that is to say, polio-lamed) he never complained of long hours, arduous travel, inadequate courtrooms or primitive accommodation. That which was good enough for the court staff was good enough for Jack Sissons.

$R v$ Stinchcombe, [1991] 3 SCR 326.

Sissons, supra note 7 at 16.

Conversation with Justice Mark de Weerdt of the Supreme Court of the Northwest Territories (19811996). 
His law, I think, was adequate to the demands of his jurisdiction.

Above all, he was a humanist — very deeply into people and their problems.

Jack Sissons always got a good press; he was colourful and controversial and he was certainly picturesque with a wolfskin parka, mukluks, and his characteristic limp. This is only [conjecture] on my part, but I think that a journalist, sometime, in the search for the felicitous phrase, described Sissons as an "angry old Man". Sissons liked this - he began referring to himself as an angry old man. The image so intrigued him that he began to work unnecessarily hard at being an angry old man. Thus, in his later years, he was often angrier than he need have been, quicker than necessary to be at odds with Ottawa on matters touching the North.

Still, who wouldn't like to be a legend in his own lifetime? ${ }^{72}$ 


\section{APPENDIX}

\section{Map of Canada Showing Sissons' JuRisdiction IN THE NORTHWEST TERRITORIES ${ }^{73}$}

[insert Map 1 (from Book)]

\section{MAP OF THE NORTHWEST TERRITORIES IN $1924^{74}$}

[insert Map 2 (from emailed file)] [map], 1:3,801,600 (Canada: Department of the Interior, 1924). 